\title{
VALUATION SYSTEMS IN POLAND, SLOVAKIA AND THE UNITED KINGDOM - COMPARATIVE STUDY
}

\author{
Marek Walacik, PhD \\ Department of Land Management and Regional Development \\ University of Warmia and Mazury in Olsztyn \\ e-mail:marek.walacik@uwm.edu.pl
}

Richard Grover, PhD

Department of Real Estate and Construction

Oxford Brookes University, MRICS,UK

e-mail:rgrover@brookes.ac.uk

\author{
Andrej Adamuscin, prof. \\ Department of Real Estate Engineering \\ Slovak University of Technology in Bratislava \\ e-mail:andrej.adamuscin@stuba.sk
}

\begin{abstract}
The real estate market is a domain of multi-faceted contemplations - ranging from economical, societal and sociological, to juridical aspects. These domains are important because they create an area of real estate (internal and external) and have an impact on the real estate market.

The multifariousness of properties has an influence on the creation of market values. Investors and people whose jobs are connected with the real estate market describe it using points, variables and characteristic attributes and on their basis, create algorithms or real estate market models. We need to draw attention to the fact that, in most cases, the terms "features ", "variables", and "attributes" are treated as the same.

The authors of the present article do not agree with that kind of approach and would like to systematize the knowledge in this area. The goal of the article is to explain problematic terms, and indicate their genesis and sense of using them. The paper compares the legal systems of property valuation in three different countries. It describes their different valuation procedures and provides commentary on them.
\end{abstract}

Keywords: property valuation, legal basis, valuation procedures.

JEL Classification: R30,A23, A29.

Citation: Walacik M., Grover R., Adamuscin A., (2013), “Valuation systems in Poland, Slovakia and United Kingdom- comparative study", Real Estate Management and Valuation, vol. 21, no. 4, pp. 7586.

DOI: $10.2478 /$ remav-2013-0039.

\section{Introduction}

Property valuation, regardless of whether it is made for market support, land taxation, mortgage or any other purpose, is a very complex process that requires the consideration of a variety of underlying market factors and the way they influence the value of a property at a given time. It is a process that 
requires valuers to possess a wide knowledge of and experience in valuation methods, property market analysis and legal acts governing property valuation. The potential for wide variability in values and the methods used to achieve them, as well as differences in the skills, knowledge, and experience of valuers, tends to result in the regulation of the valuation process and, by implication, of the valuers themselves. The paper considers the systems of regulation in three contrasting countries. Poland and Slovakia are both transition economies, which had to develop systems of property valuation once free markets in property rights were established after 1989. They have turned to regulation that is determined by statute law and state regulations. By contrast, the UK has little by way of direct government involvement in the regulation of valuations and has adopted a selfregulatory model in which valuers tend to regulate themselves. Those who are aggrieved by the quality of valuations can sue valuers for negligence in the courts.

\section{Property valuation legal basis in Poland and Slovakia}

The main legal acts dealing with property valuation in Poland are the Land Management Act, dated 21 August 1997, and the Directive of the Cabinet, dated 21 September 2004, regarding real estate valuation and preparation of appraisal reports. The aforementioned regulations are amongst many to recognize real estate appraisal as a professional activity performed by real estate appraisers, define a real estate appraiser, determine their rights and obligations, introduce professional liability of real estate appraisers, and set out the principles of granting professional qualifications to them. Moreover, they make professional standards mandatory, give the exclusive right to value real estate to real estate appraisers, introduce obligatory civil liability insurance of real estate appraisers for damage done in connection with errors in real estate appraisal and, finally, determine the principles of real estate appraisal.

What was set out in two legal acts in Poland, can be found in the following four in Slovakia:

1) Act No. 382/2004 Coll., on Experts, Interpreters and Translators, and in amendments to certain laws, as amended.

2) Decree No 490/2004 Coll. of the Ministry of Justice of the Slovak Republic implementing Act No 382/2004 Coll., on Experts, Interpreters and Translators and in amendments to certain laws, as amended.

3) Decree No. 491/2004 Coll. of the Ministry of Justice of the Slovak Republic on Awards, Reimbursement of Expenses and Compensation for Wasting Time of Experts, Interpreters and Translators, as amended.

4) Decree no. 492/2004 Coll., on determination of General Assets Value.

What differs between the two countries in the matter of legal basis is that the procedures of property valuation in Poland were described in the professional valuation standards, which are harmonized with valuation standards of a higher level (GRZESIK, ŹRÓBEK, 2012) as presented in Fig. 1, whereas in Slovakia, the procedures were set in the Regulations of the Ministry of Justice. This means that Polish standards are harmonized with International and European Valuation Standards.

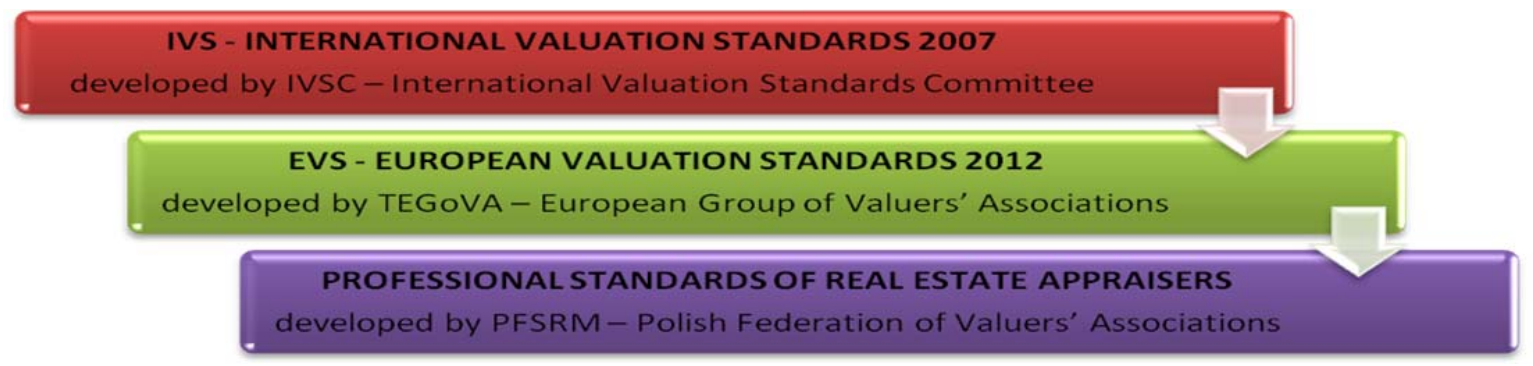

Picture 1. Harmonization of valuation principles in professional standards, Source: authors' own study.

In contrast to both Poland and Slovakia, the UK has no laws on property valuations. There is a well-developed system of professional negligence law led, as the UK is a common law country, by the interpretation of the courts as to what a reasonably competent valuer should be capable of achieving. Although there are no laws preventing anyone from calling himself a valuer and carrying out property valuations, any such person is expected to deliver services to the accepted standard, irrespective of his or her qualifications and experience or the lack of them; ignorance is no excuse. 
Someone lacking the requisite knowledge and experience will quickly find himself bankrupted by litigation and compensation, assuming that anyone would employ a valuer who did not have professional indemnity insurance. An unqualified person could not obtain such insurance. The courts are inclined to accept the standards developed by the Royal Institution of Chartered Surveyors (RICS) and specified in its so-called Red Book as defining what a competent valuer must achieve and are only willing to accept a small margin of error in valuations. The Red Book incorporates the standards of the International Valuation Standards Council. In effect, although there are no valuation laws in the UK, the situation in practice is not so different from that in Poland, even if it is driven by selfregulatory bodies enforcing standards on their members rather than statute. Their members agree to follow the standards or face disciplinary action. This is a voluntary decision, though without doing so they are unlikely to secure work as a valuer. No rational client would employ a valuer who was not a member of such a body.

\section{Procedures of property valuation in Poland and Slovakia}

Establishing the general value of property in Slovakia is controlled by the Regulation of the Ministry of Justice of the Slovak Republic no. 492/2004 Coll. on the Determination of General Assets Value, as amended (hereafter referred to as the regulation). This regulation includes sixteen appendices which make provision for various aspects of the particular constituents of property and their technicaleconomical assessment (real estate assets, intangible assets, vehicles, machinery, etc.). The process of establishing the general value of real estate assets follows appendix no. 3 "Process of determining the general value of real estate assets", according to which general value (VŠH) is the objective value of buildings and properties. It is an expert assessment of their most probable market price achieved on the valuation date under conditions of free competition, fair trade between a willing buyer and a willing seller in an arm's length transaction, after proper marketing and with the parties having each acted knowledgeably, prudently and without compulsion, under the presumption that the price was not influenced by an inadequate motive. The regulation additionally introduces the notion of yield value (HV) which is an expert assessment of the present value of future disposable income acquired from property rental after deducting the risk-adjusted discount rate.

According to the regulation, methods of determining the general value of land and buildings are not the same; therefore, these two processes are further described independently.

The general value of land (VŠHPOZ) is established using these approaches:

1) the sales comparison approach,

2) the income capitalization approach (used for land which is able to generate revenue from rental),

3) the localization differentiation approach (or method of positional differentiation).

The selection of an appropriate method is performed by an expert and must be justified. Depending on the purpose, an expert valuation report can use several methods simultaneously but, in the end, they will be listed only as justification of the market value determined by the selected method, which best describes the definition of general value.

Price calculation in the sales comparison approach is undertaken using a transactional approach. At least three other properties are used for comparison and the metric unit of 1 square meter is applied. Differences between the compared lands and the appraised land must be taken into account. When comparing permanent vegetation excluding the land, the utilized metric unit is determined according the type of vegetation (one tree, 1 hectare permanent grassland, etc.). Key factors for comparison can be divided in the following groups:

a) economic - transaction date, form of transaction, method of payment, etc.,

b) geographical - place, position, attractiveness, accessibility, etc.,

c) physical - infrastructure, construction possibilities on a building lot, soil quality, quality of plantation on other lands, etc.

The documents used for comparison (transfer contract, real estate agency bid) must be identifiable. Additionally, all extraordinary circumstances (family relations between the buyer and seller, state of emergency of the buyer or seller, etc.) must be ruled out. Statistical mathematics can also be used to calculate the price, but the sample has to be large enough for the specific statistical method applied.

The income capitalization approach is calculated as capitalizations of future withdrawable resources within an unlimited time frame using the formula: 


$$
V_{S} \mathrm{H}_{\mathrm{POZ}}=\frac{\mathrm{OZ}}{\mathrm{k}} \quad[€],
$$

where:

$\mathrm{OZ}$ - withdrawable resource. This is the disposable income achievable from property rental. For agricultural and permanent grasslands, in specific cases, it is permissible to use disposable income from agricultural or forest stock. Net income is defined as an entity's income minus expenses [€/year].

$\mathrm{k}$ - Interest rate. A decimal form of interest rate is used in the formula [\%/100]. Minimal interest rate in percentages is equal to 1.5 times the base interest rate of the European Central Bank. Tax income is also taken into account when assigning the interest rate.

The localization differentiation approach (or method of positional differentiation) deals only with determining the general value of land in a built-up urban area of non-agricultural, non-woodland land, and general value of building land not yet build-up. The general value of land (VŠHPOZ) determined using the location differentiation method is calculated as land size $\mathrm{M}$ (in square meters) multiplied by the general land value unit [VŠHMJ]. The general value of land is, therefore, calculated as:

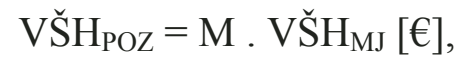

The unit general value of land [VŠHMJ] is calculated as the initial unit value of land [VHMJ] multiplied by the coefficient of localization differentiation [kPD]. The unit general value of land is, therefore, calculated as:

$$
\mathrm{V} \breve{S} \mathrm{H}_{\mathrm{MJ}}=\mathrm{VH}_{\mathrm{MJ}} \cdot \mathrm{k}_{\mathrm{PD}}\left[€ / \mathrm{m}^{2}\right],
$$

The initial unit value of land is determined based on a town/city classification chart.

Table 1

Town/city classification

\begin{tabular}{lc}
\hline \multicolumn{1}{c}{$\begin{array}{c}\text { Town/city classification - } \\
\text { name or entry based on citizen count }\end{array}$} & $\mathbf{V H}_{\mathbf{M J}}\left[€ / \mathbf{m}^{2}\right]$ \\
\hline a) Bratislava & 66.39 \\
\hline $\begin{array}{l}\text { b) Regional cities: Nitra, Prešov, Trenčín, Trnava, Žilina, } \\
\text { Košice, Banská Bystrica a mestá: Piešt́any, Vysoké Tatry, } \\
\text { Trenčianske Teplice }\end{array}$ & 26.56 \\
\hline c) Cities: Poprad, Zvolen, Liptovský Mikuláš, Martin & 16.60 \\
\hline d) Other district towns with regional or district state bureaus & 9.96 \\
\hline e) Other towns above 15,000 citizens & 6.64 \\
\hline f) Other towns between 5,000 and 15,000 citizens & 4.98 \\
\hline g) Other towns between 2,000 and 5,000 citizens & 3.32 \\
\hline h) Other towns up to 2,000 citizens & 1.66 \\
\hline
\end{tabular}

Source: Ministry of Justice regulation no. 492/2004 Coll. Determination of General Assets Value.

The unit initial value of land in towns and other habitats surrounding a city where there is a higher market demand for land (for purposes of residency or recreation) can be as high as 70\% of the unit initial value of its respective city. In the case of interest in other types of real estate, its initial value can be up to $50 \%$ of the unit initial value of its respective city (the city being the driver of interest). In these cases, the coefficient of localization differentiation is related to the city that is the driver of interest. The localization differentiation coefficient is calculated as a result of six indexes describing the impact of localization and other factors affecting the value of land:

where the:

$$
\mathrm{k}_{\mathrm{PD}}=\mathrm{k}_{\mathrm{S}} \cdot \mathrm{k}_{\mathrm{V}} \cdot \mathrm{k}_{\mathrm{D}} \cdot \mathrm{k}_{\mathrm{P}} \cdot \mathrm{k}_{\mathrm{I}} \cdot \mathrm{k}_{\mathrm{Z}} \cdot \mathrm{k}_{\mathrm{R}}[-] \text {, }
$$

$\mathrm{k}_{\mathrm{s}}$ - general situation index is divided into eight classes from 0.70 to 2.00 ,

$\mathrm{k}_{\mathrm{V}}$ - intensity of use index is divided into seven classes from 0.90 to 2.00,

$\mathrm{k}_{\mathrm{D}}$ - traffic relations index is divided into six classes from 0.80 to 1.20 ,

$\mathrm{k}_{\mathrm{P}}$ - business or industry location index is divided into five classes from 0.90 to 2.00 , 
$\mathrm{k}_{\mathrm{I}}$ - land type and provision index is divided into eight classes from 0.60 to 1.50 ,

$\mathrm{k}_{\mathrm{P}}$ - index of advantage or disadvantage factors is divided into two classes:

factors of advantage from 1.00 to 3.00 ,

factors of disadvantage from 0.20 to 1.00 .

Factors of advantage are lands determined by a respective development plan to be used for a higher purpose than their current use, corner parcels for commercial use, lands with a construction closure in protected territory, business parcels in places of high tourist traffic (if not accounted for in the general situation index), lands in substantially high market demand (if not accounted for in the initial value of land), areas with significant tax breaks, etc. The factors of advantage or disadvantage are usable only if they have not already been taken into account in the initial land value or other coefficients. Taking all these factors into account, the resulting value of the localization differentiation index of land can vary greatly. It is, therefore, limited by a minimal and maximal value: min. $\mathrm{kPD}=$ 0.054 and max. $\mathrm{kPD}=43,200$.

The general value of buildings in Slovakia is determined using these methods:

1) the sales comparison approach,

2) the localization differentiation approach (or method of positional differentiation),

3) the mixed approach (or the combined method; used for buildings which are able to generate revenue from rental).

The selection of an appropriate method is performed by an expert and must be justified. Depending on the purpose, an expert valuation report can also use several methods simultaneously but, in the end, they will be listed only as justification of the market value determined by the selected method which best describes the definition of general value.

Price calculation in the sales comparison approach is undertaken using a transactional approach. At least three other properties are used for comparison. Varying metric units, which take into account the differences between the compared and appraised objects - build up area, build up space, floor area, length, etc.), are used.

The key factors for comparison are:

a) economic - (transaction date, form of transaction, method of payment, etc.),

b) geographical - (place, position, attractiveness, accessibility, etc.),

c) constructional and physical - (standard, above standard, substandard, accessories, etc.).

The documents used for comparison (transfer contract, real estate agency bid) must be identifiable. Additionally, all extraordinary circumstances (family relations between the buyer and seller, state of emergency of the buyer or seller, etc.) must be ruled out. Statistical mathematics can also be used to calculate the price, but the sample has to be large enough for the specific statistical method applied.

The localization differentiation approach (or method of positional differentiation) for the general value of buildings is calculated as the technical value of the building factor $(\mathrm{TH})$ multiplied by the localization differentiation index, which describes the impact of localization and other factors impacting the value of a building. Technical value (TH) is an expert estimate of the initial building value reduced by the value corresponding to building deprecation. Initial value $(\mathrm{VH})$ is an expert estimate of the value for which the building was acquirable through construction at the time of the estimation without tax.

Calculation of the initial value $(\mathrm{VH})$ is done based on budget coefficients. The budget coefficient must be verifiable, meaning that the selected coefficient is identified by name and respective number in the building classification codebook, and base unit value determined according to publicly accessible catalogues issued by the respective ministry. Unit value is modified in a verifiable manner based on the various characteristics of the evaluated object (floor height, yardage, available facilities within the object, construction and material characteristics, etc.). These factors are transferred into the price (their value correspondent with the date on which the appraisal is made).

Initial value is then assessed as a factor of budget coefficients (RU) and units of measure (M).

$$
\mathrm{VH}=\mathrm{M} \cdot(\mathrm{RU} \cdot \mathrm{kCU} \cdot \mathrm{kV} \cdot \mathrm{kZP} \cdot \mathrm{kVP} \cdot \mathrm{kK} \cdot \mathrm{kM})[€],
$$

This value is further modified by six correctional indexes:

1) $\mathrm{kCU}$ - index describing the development of construction costs between the date of the appraisal and the period for which a budget coefficient of a compared object was made. 
2) $\mathrm{kV}$ - index describing the impact of available facilities within the evaluated object. Deals with the price difference between the construction and facilities of evaluated and compared objects.

3) $\mathrm{kZP}$ - index describing the impact of a built-up area surrounding the evaluated object. Describes the difference between the construction price and facilities dependent on the built-up area compared to the average built-up area of a compared object.

4) $\mathrm{kVP}$ - index describing the impact of the construction floor height of the evaluated building. Describes the price difference of the construction and facilities depending on the construction height compared to the average construction height of evaluated and compared buildings.

5) $\mathrm{kK}$ - index of construction-material characteristics. Describes the price difference based on the material used for the supportive structure of the building.

6) $\mathrm{kM}$ - index describing territorial impact. Describes the increased or reduced costs of construction at a specific place connected with transportation distances, possibilities of facilitating the construction site, etc.

Calculating the technical condition (TS) and technical value (TH)

Building deprecation is stated in percentages and corresponds to the deprecation of technical condition based on the age of the building, its estimated life span, means of building usage, approach to building maintenance, etc. It is calculated using a linear and analytic approach.

The deprecation of building superstructures, extensions and independently evaluated parts are calculated separately for each year of their life span using a linear approach, but the end of a building's life span is then determined as the same for the whole building. Total building deprecation (using a linear approach) can be calculated as the weighted average of deprecation of its individual parts. The metric unit is identical to the one that was used for calculating the initial value.

The technical condition is reported in percentages and calculated as the difference between the initial value $(100 \%)$ and the extent of building deprecation.

The following terms are used when calculating the building deprecation value:

- Building age $(\mathrm{V})$ - is the difference between the year of building valuation and the year in which the final building approval was issued. If the building was put into use before an approval decision was issued then, for the purposes of building age calculation, the respective number of years is deducted from the year of building valuation. The year in which the building was put to use must be provable. If it is not provable, then other relevant documents are used to determine the date. If such documents do not exist, a substantiated expert estimate is undertaken.

- Base building life span (ZZ) - is the anticipated life span of a given building type, assuming standard maintenance is undertaken from the commencement of the life cycle up until building destruction, declared in years.

- Building life span $(Z)$ - is the anticipated life span of a specific building, assuming standard maintenance is undertaken from the commencement of the life cycle up until building destruction, declared in years. An accredited professional declares the building life span based on its construction-material characteristics, technical condition, means and intensity of usage and administered maintenance.

- Depreciation value (HO) describes the scope of building depreciation and is calculated as the sum of depreciation values of the individual building parts.

\section{General value of buildings}

Using the localization differentiation approach, an individual value is determined for:

a) The whole building, excluding housing and non-residential premises,

b) Housing and non-residential premises.

The general value of buildings, excluding housing and non-residential premises, is calculated as the building technical value (TH) multiplied by the localization differentiation index, which describes the impact of the localization and other factors on the price at the current time and place. This index is determined by a weighted average of 20 factors, which are listed in appendix no. 3 of the Regulation of the Ministry of Justice of the Slovak Republic no. 492/2004 Coll. on the Determination of the General Assets Value, as amended.

The general value of housing and non-residential premises is calculated as the technical value (TH) of housing or non-residential premises multiplied by the localization differentiation index, which 
describes the impact of localization and other factors impacting the price at the current time and place. This index is determined by a weighted average of 17 factors which are listed in appendix no. 3 of the Regulation of the Ministry of Justice of the Slovak Republic no. 492/2004 Coll. on the Determination of General Assets Value as amended.

The expert uses a mixed approach to determine the general value of a building as a weighted average of the yield value and technical value of the building. The yield from land is not included in the building yield value. When the building yield and building technical values are roughly the same, or the yield value is higher than the technical value, the scales rectifying both values are the same. In all other cases, the rectifying scale of the building yield value is higher than the rectifying scale of the building technical value.

Building yield value (HV) is calculated through the capitalization of future disposable resources for an unlimited period of time or through the capitalization of future disposable resources during a limited period of time followed by selling the building. An expert must determine the method of calculating building yield value.

What in Slovakian valuation law is defined as "general value", is called market value in the Polish legal system. Although the two definitions were formed in a different way, they have the same meaning. Real estate market value in Poland means the most probable market price resulting from the analysis of transaction prices, assuming that:

- The parties of the transactions were entirely independent of one another, were not acting under duress and were willing to draw up an agreement,

- The time necessary to place the property on the market and negotiate the agreement had passed (proper marketing).

As far as the procedures of property valuation are concerned, the solutions adopted in Poland differ from the ones found in Slovakia. The classification of means of market value valuation is presented in Fig. 2.

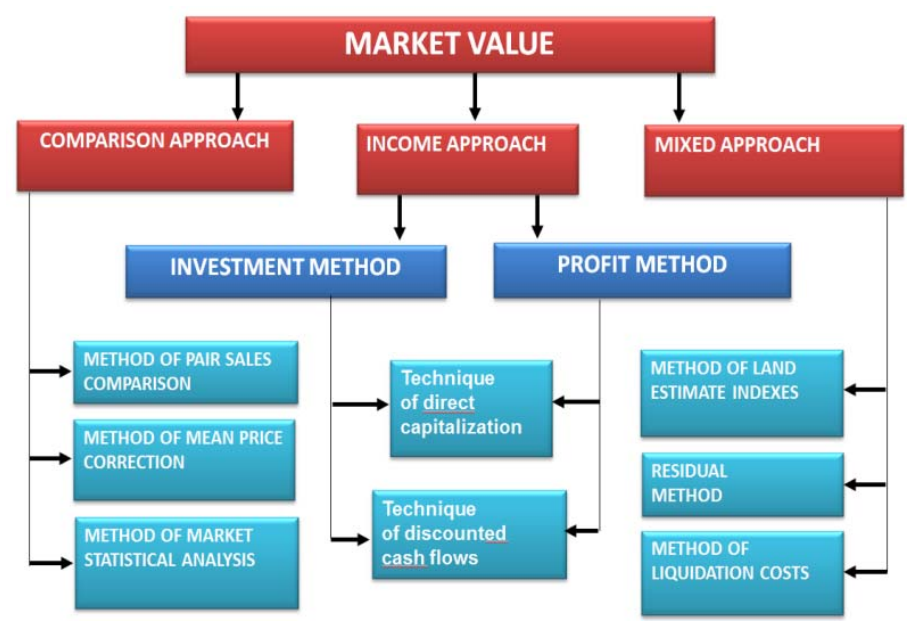

Fig. 2. The classification of means of market value valuation, Source: the Directive of the Cabinet dated 21 September 2004 regarding Real Estate Valuation and Preparation of Appraisal Reports.

First of all, the process of property valuation is not divided into two parts. If the property valuer has to determine the value of a built-up property, he or she estimates the value of the land together with the building. Moreover, in order to do that, there is a method available in Poland that is not found in any other country - the method of mean price correction (because of the limited length of the paper, the authors will focus only on this one method to show the differences in valuation procedures).

When using the method of mean price correction, the appraiser needs to take into consideration at least a dozen comparable properties from the relevant market which have recently been sold and the transaction prices, conditions and features of which are known. To determine the value of the analyzed property, the appraiser adjusts the average price of comparables using adjusting ratios which take into account the differences in the particular features of these properties.

The procedure for the average price correction method involves the following steps: 
1) describing the analyzed property,

2) determining the size of a representative sample of comparable properties,

3) revising unit prices for the date of the appraisal,

4) calculating the arithmetic mean of transaction prices $\left(\mathrm{C}_{\mathrm{AVG}}\right)$,

5) identifying features differentiating the properties and measuring their levels,

6) describing the cheapest property within the sample ( $\left.\mathrm{C}_{\text {MIN }}\right)$,

7) describing the most expensive property within the sample ( $\left.\mathrm{C}_{\mathrm{MAX}}\right)$,

8) calculating the marginal values of the sum of adjusting ratios:

- lower range of the sum of adjusting ratios

$$
\frac{C_{M I N}}{C_{\dot{S} R}}
$$

- upper range of the sum of adjusting ratios

$$
\frac{C_{M A X}}{C_{S R}}
$$

9) determining the weights of features in $\Delta C$ for each comparable,

10) establishing the range of adjusting ratios for each feature,

11) calculating the value of the adjusting ratio (ui) for each feature of the analyzed property,

12) determining the unit value $(\mathrm{Wj})$ of the analyzed property according to the following formula:

$$
W_{J}=C_{\dot{S} R} \times \sum_{i=1}^{n} u_{i}
$$

13) drawing a conclusion regarding the final value of the analyzed property.

In spite of the fact that Poland and Slovakia have developed different procedures of property valuation, they have one rule in common - property valuation can only be done by experts representing the profession of property valuers. In the UK, whilst it is legal for unqualified persons to act as valuers, in practice, the situation is the same as in Poland and Slovakia. No bank or other financial institution or company would commission a valuation from an unqualified person. Individual persons might be foolish enough to do so, however, the main reason why individuals commission valuers is for mortgage purposes, and banks will only accept valuations from qualified persons. Therefore, individuals have no choice but to employ qualified valuers.

As has been noted, the approach to valuations in the UK is determined by the International Valuation Standards Council (IVSC), whose standards are incorporated into the RICS Red Book. In addition to this, there are standards and a guidance that are related to purely British situations, such as how to value local authority housing. The key question for the valuer is whether the valuation is one for the use of the client and the client alone, or if it is likely that it will be relied upon by a third party, for example, for mortgages or company accounts. Private valuations can be based on whatever assumptions the client thinks are appropriate, but ones that are performed for the public or a third party use must be based on IVSC principles. This generally means valuing for the highest and best use, assuming that, following adequate marketing, there will be a willing buyer and seller.

The preferred method is the comparison method for either the sales price for selling or rental price for leasing. The investment method, using a market-determined risk-adjusted yield, can convert the rental value into the sales value through capitalization or the capital value into the rental value through decapitalization. The receipts and expenditure method (profits method) is used for those properties traded as business entities, particularly businesses associated with recreation, such as hotels, bars and tourist attractions. The contractor's test (depreciated replacement cost) method is used as a last resort, when no market evidence is available because the properties are not traded, and the services produced are either not sold or are sold for a controlled price, so that the receipts and expenditure method cannot be used. These are mainly public sector properties, such as schools, hospitals and prisons. The method can also be used for industrial plants like steelworks and petrochemical works. The assumption is that the property is worth at least its replacement value or else the occupier would have ceased occupation. Other methods are available for the calculation of worth, in other words, what the property is worth to the user or a potential buyer, but they are not measures of value as they do not measure the exchange value or market price. These include the residual method, 
often used to assess the worth of development sites. Normally, the market value of a property is estimated at its highest and best use, though valuations for annual taxes on property use market value at the existing use.

\section{The profession of property valuers in Poland and Slovakia}

According to Polish law, a real estate appraiser has to meet the following requirements:

- have the capacity to enter into legal transactions,

- have not been convicted of offences against property or documents, economic offences, forging money, securities or official stamps, fiscal offences, or any other offences which are relevant to the profession,

- hold a university degree - master's degree in all disciplines

- have completed post-graduate studies in real estate appraisal,

- have completed professional practical training in real estate appraisal,

- have successfully completed the qualification procedure, including passing the examination which grants qualifications for real estate appraisal.

The requirements specified in the Slovakian legal system are similar. If an individual wants to become a valuer, he or she has to:

- have the capacity to perform legal acts in law,

- be irreproachable (in legal terms),

- have completed education in the field that is the subject of the request,

- have completed special training on conducting activities outlined by the act (hereafter referred to as the professional minimum),

- have been actively involved in the building and construction industry for at least seven years,

- have passed a test from the professional field or branch that is the subject of the request, and demonstrates the professional competence of such an individual (hereafter referred to as the proficiency test),

- have successfully completed specialized education, if the subject of the request is an area of expertise that requires this according to the implementing Decree issued by the Ministry of Justice of the Slovak Republic,

- possess the material equipment sufficient for carrying out activities in the respective field,

- not have been lawfully suspended from the list of experts in the last three years or prohibited to perform activities in the respective field,

- have taken a pledge before the Ministry of Justice of the Slovak Republic.

What seems comparable in the Slovakian and Polish legal background looks completely different in the United Kingdom. Qualified valuers are those who are members of a reputable professional body of valuers. The overwhelming majority of valuers are members (or fellows) of the Royal Institution of Chartered Surveyors (RICS). There are also some smaller bodies, including ones that specialize in areas like tax or agricultural valuations, most of whose members are also members of the RICS.

Membership of the RICS requires obtaining a degree or diploma from an accredited university; universities throughout the world have been accredited by the RICS. The degree can be a first degree or master's degree. Those doing master's degrees have usually taken a first degree in an unrelated subject. Graduates then usually spend approximately two years undertaking supervised practice and training in the workplace before taking the Assessment of Professional Competence. During these two years, they must gain a number of days' experience in various competencies at different levels. Once qualified, all members must maintain professional competence.

This self-regulatory system can function because insurers will only grant professional indemnity insurance to valuers who are members of a reputable professional body and the leading clients, principally financial institutions, will only employ competent valuers. The government will also employ only qualified valuers in areas like tax valuation and compulsory purchase, employing approximately 1,350 of them in its Valuation Office Agency, which provides valuation advice to the rest of the government in addition to performing property tax assessments.

\section{UK's solutions in comparison to Poland and Slovakia}

Visitors to the United Kingdom are often surprised by its strangeness and the contradictions that its 
citizens take for granted. It is a country that buys its petrol in liters but insists on measuring its roads in miles. It is a democracy whose head of state is (in theory) an absolute hereditary monarch. It puts on military shows like the Changing of the Guard using soldiers from some of its most feared combat units. Its property market is similarly bewildering to visitors from Central and Eastern Europe. It is one of the world's most active markets, welcoming to foreign investors, with a reputation for transparency and professionalism and yet, there is no law on valuation; nor is there any state regulation of valuers. Anyone can call him- or herself a valuer and offer valuation services. The profession of "valuer" is not a protected one in the way that, say, "a doctor", "an architect", "an auditor", or "an insolvency practitioner" is. Members of these professions are licensed and it is illegal for someone who is not licensed to use such a title or practice the profession. This puts the UK in a very different position from the other two countries examined in this article. Both Poland and Slovakia have laws on valuation and regulate who can carry it out and the methods which are to be used. The contrast raises important questions about whether state regulation of valuation is necessary and, if there is to be state regulation, how it might best be carried out.

The absence of valuation laws in the UK should not be interpreted as meaning that valuation is outside of the law. Like every other activity in the UK, valuation is subject to the rule of law and legal action can be taken against valuers by those who have suffered a loss as a result of errors in valuations. The UK has a common law system rather than a system of legal codes. The general presumption is that any activity that is not illegal is legal. Laws have to be enacted to prevent activities from taking place rather than permitting them to take place. There are exceptions to this general principle and public bodies tend to be subject to strict ultra vires restrictions that prevent them from carrying out any activities that they are not explicitly permitted by law to undertake. The presumption of legality produces a flexible economic environment in which entrepreneurs can respond to changes in demand or production opportunities. The government tends to be involved in regulation in response to public concerns about safety, fairness, fraudulent or misleading activity, or the need for public protection. Thus, doctors and architects are regulated, as malpractice by them could result in death or injury while auditors and insolvency practitioners (those who wind up the affairs of bankrupt individuals and companies) are regulated in order to protect the public against fraud. However, a fundamental principle in commerce has been caveat emptor, let the buyer beware, meaning that buyers should satisfy themselves about the goods or services they purchase rather than look to others or the state for protection.

It is easy to see how these notions of the legality of activities that are not expressly prohibited or regulated and it being the buyer's responsibility not to be duped could degenerate into a state of anarchy in the market, in which each person is pitched against everyone else in a desperate scramble to pursue his self-interest at the expense of others. In practice, markets frequently involve repeated transactions between buyers and sellers rather than one-off purchases. The parties, therefore, have the opportunity to build up knowledge about buyers and sellers so that transactions are entered into on the basis of best value rather than best price. A seller who is known to be disreputable may be avoided, no matter how tempting the offered prices are. Transactions are also governed by the rule of law. Clients of valuers can sue for compensation for their losses where the standards of the service received are not those of a reasonably competent practitioner, with the courts empowered to determine what those standards are on the basis of evidence submitted by the plaintiff and the defendant. In a common law system, courts can determine cases on the basis of equity and precedent, even with there being no laws in the area.

There are certain situations in which governments are likely to respond to calls for regulation. Monopolies are able to control the market and consumers may be faced with paying higher prices for fewer or inferior goods or services than would be supplied in a competitive market. This is potentially an issue where practitioners form a professional body and the members of this body have a monopoly over the supply of services in an area. The competition policy in the UK does not presume that a monopoly is necessarily a bad thing, but that it involves a quasi-judicial investigation by the Competition Commission. The Competition Commission assesses the extent to which the public benefits from the controls over standards that a professional body can exercise over its members compared with the impact of reduced competition on the public, such as higher prices. Professional bodies are periodically subject to review by the Competition Commission, which may require them to abandon practices it sees as anti-competitive. For example, the Royal Institution of Chartered Surveyors is prohibited from publishing scales of recommended fees for work, which was seen as 
preventing competition between its members.

Another factor that can encourage government regulation is when there is asymmetrical knowledge between the parties in a transaction. This happens when one party, often the seller, possesses information that the other, usually the buyer, does not. An assumption behind efficient markets is that buyers and sellers are fully informed about market circumstances. Asymmetrical information is particularly likely to occur where the seller has knowledge as a result of his professional expertise and experience in the market, and the buyer rarely buys the service and, therefore, has little experience or expertise. Here, the government may seek to regulate the market to ensure that the buyer receives a minimum quality of service and is not subjected to unfair terms and conditions that benefit the seller. Generally, companies are deemed to be able to take care of their own interests, thus state intervention in the event of asymmetrical information tends to be aimed at protecting the consumer. Even then, the preferred method of regulation may be through a voluntary code of practice or self-regulation. The problem that governments face is that their knowledge about an area may be inferior to that of the practitioners, and so they may need to make use of such people's expertise in order to regulate the area effectively. State regulators, in some situations, are prone to regulator capture in which they become dependent on those they regulate for information so that, in effect, they act in the interests of the regulated. Self-regulation can achieve higher standards as the professional body seeks to weed out poor practice that contaminates its public image.

The government does sometimes come under pressure from professional bodies to intervene to regulate an activity, particularly where their members find themselves in competition with unregulated businesses. For example, the RICS has been pressing the government to regulate residential letting agents, some of whom exploit tenants through failing to carry out repairs and seeking to recover damages from deposits that are not justified. RICS members are subject to the body's standards in their business and claim that they are undercut on price by those who do not adhere to the same standards. Some landlords may choose a letting agent on the basis of the fee charged rather than the quality and integrity of the services offered.

Valuation services are seen in the UK as a private transaction between willing buyers and sellers. Valuers are not seen as court experts determining "the" value of a property. Where a third party (other than the person commissioning the valuation) can be foreseen to rely on the valuation, for example, in valuations of properties for balance sheets, it can be argued that they are able to sue valuers in the event of negligence. The UK has an adversarial court system in which lawyers representing the plaintiff and defendant can cross examine witnesses and challenge evidence. This also applies to disputes over valuations, for example, appeals against property tax assessments. The testing of evidence should help to bring about true market valuation in such cases. Each party can bring forward evidence from its own valuers and can call expert witnesses. In principle, the role of expert witnesses is to assist the court, but the plaintiff and defendant can call their own. As valuers are not experts appointed as servants of the court, they do not enjoy legal immunity and can be sued for negligence.

\section{Conclusions}

Could the UK's approach to self-regulation work in Poland or Slovakia? The answer is probably no. Firstly, as has already been noted, the UK has a common law system so the courts can consider any dispute referred to them, irrespective of whether there are laws or not. They can decide cases using precedent and equity. Secondly, professional bodies developed a long time ago, around the time that sport was becoming professional and the rules codified, i.e., at the end of the nineteenth century. The UK system has evolved over a long period of time. Transition economies have had to create fullyfledged systems soon after their property markets became legal. Market economies have had centuries to evolve rules of how markets ought to behave. Thirdly, the system depends upon professional indemnity insurance so that those who suffer a loss as a result of poor quality valuations can be compensated. Such insurance can only exist if negligence is defined. Professional indemnity insurance is in its infancy in transition economies. Instead of copying the UK's approach, Poland and Slovakia have sought to achieve the same outcomes using means that are more likely to work effectively in their economies at the present time. It may be desirable over time for valuations to become more deregulated as the market matures and requires greater flexibility, but that is an issue for the future. 


\section{References}

ACт No. 382/2004 Coll., on Experts, Interpreters and Translators as amended.

The instruction of Ministry of Justice of the Slovak republic no. 7/2009

Decree No 490/2004 Coll. of the Ministry of Justice of the Slovak Republic implementing Act No 382/2004 Coll., on Experts, Interpreters and Translators and on amendments certain laws, as amended.

Regulation of Ministry of justice of Slovak republic no. 492/2004 Coll. on determination of General Assets Value as amended

ADAMUSCIN A., 2010, The investment instruments in real estate market. Bratislava: Statis, 2010. $167 \mathrm{~s}$. ISBN 978-80-85659-63-4.

JURAJ B., 2012, Real Estate ownership and property taxes, Journal of Real estate \& Housing. Bratislava. ISSN 1336-944X.

Land Management Act dated 21 August 1997

Directive of the Cabinet dated 21 September 2004 regarding real estate valuation and preparing the appraisal report

GRZESIK K., ŹRÓBEK S., 2012, Harmonisation of valuation standards worldwide and evolution of different interpretations of market value, Topical issues in the valuation and the application of market value, Olsztyn. 